\title{
Estimation of prevalence and incidence of subclinical mastitis in a large population of Brazilian dairy herds
}

\author{
Marcos Busanello, ${ }^{*}$ Rodolfo S. Rossi, $†$ Laerte D. Cassoli, ${ }^{*}$ José C. F. Pantoja, $†$ and Paulo F. Machado*1 \\ *Department of Animal Science, Luiz de Queiroz College of Agriculture, University of São Paulo, Avenida Pádua Dias, 11, Piracicaba, São Paulo, \\ Brazil, 13418-900 \\ †Department of Veterinary Hygiene and Public Health, School of Veterinary Medicine and Animal Science, São Paulo State University, Botucatu, \\ São Paulo, Brazil, 18618-970
}

\section{ABSTRACT}

The objectives of this study were to estimate the prevalence and incidence of subclinical mastitis (SM) in a large population of Brazilian dairy herds and to describe how these indices changed over time. A data set comprising individual cow somatic cell counts (SCC) from 18,316 test days (TD) of 1,809 herds that participated in a Dairy Herd Improvement Association (DHIA) program between January 2011 and May 2015 was available for analysis. Only tests that had $\geq 10$ lactating cows and that were performed at $30 \pm$ 10 -d intervals were used for analysis. The final data set included 8,285 TD from 517 herds located in 5 regions of the country. Prevalence (\%) of SM was defined as the number of cows with SCC $\geq 200,000$ cells $/ \mathrm{mL}$ divided by the total number of tested cows on a given TD. The incidence of SM was defined as the number of cows whose SCC increased from $<200,000$ to $\geq 200,000$ cells/mL over 2 consecutive TD divided by the sum of each cow's days at risk during this interval, expressed as new cases per cow month at risk. Prevalence and incidence of SM were compared among years, regions, herd size categories, and frequency of DHIA testing during the study period. The overall mean prevalence and incidence of SM including all tests performed during the study period was $46.4 \%$ and 0.17 new cases per cow month at risk, respectively. The prevalence of SM varied little from 2011 to 2015, and an increasing trend was observed over the years. Prevalence was lower in herds that performed $\geq 60$ DHIA tests during the study period than in those that performed fewer tests and was not different among regions or herd size categories. Incidence of SM varied little over the years and was not different among the regions studied. Prevalence and

Received September 24, 2016.

Accepted May 3, 2017.

${ }^{1}$ Corresponding author: pmachado@usp.br incidence of SM in the 517 herds studied were high and did not improve over the years. These trends were observed across all herd size categories and regions studied. Producers who had more DHIA tests performed per herd during the study period had lower prevalence of SM. Results of this study highlight the need to establish large-scale milk quality programs in Brazil.

Key words: udder health, milk quality, bovine mastitis, epidemiology

\section{INTRODUCTION}

Subclinical mastitis (SM) is the most prevalent disease of dairy cows. Although SM is characterized by the absence of clinical signs and milk can still be marketed, it results in several detrimental effects on dairy production, such as reduction in production and quality of milk and dairy products (Barbano et al., 2006). Estimation of epidemiologic indices is critical in mastitis control programs to study the dynamics of SM within the herd. Prevalence estimates the proportion of infected cows at a fixed point in time, and incidence estimates the rate of new IMI over time. Both indices are essential for determining the scope of mastitis problems in dairy herds and assessing the efficiency of control measures (Ruegg, 2003). Prevalence and incidence of SM have been estimated worldwide from monthly individual cow SCC performed by DHIA laboratories. Composite milk SCC is an inexpensive test with enough accuracy to allow diagnosis and management of SM at the herd level; its sensitivity and specificity at a threshold of 200,000 cells/mL have been reported as between 73 and $89 \%$ and between 75 and $86 \%$, respectively (McDermott et al., 1982; Dohoo and Leslie, 1991).

Results of regional studies performed in Brazil indicate a wide variation in the cow-level prevalence of SM: Pará, 15.6\% ( $\mathrm{n}=9$ herds; Oliveira et al., 2011); Bahia, 38.5\% ( $\mathrm{n}=10$ herds; Oliveira et al., 2010); Minas Gerais and São Paulo, 46.1\% ( $\mathrm{n}=34$ herds; Costa et al., 1999); Rio Grande do Sul, 53\% (n = 16 herds; Ziech et al., 2013); Minas Gerais, $55.4 \%(\mathrm{n}=44$ 
herds; Cunha et al., 2015); and São Paulo, 63.6\% (n = 5 herds; Bueno et al., 2002). Other researchers studied $\mathrm{SM}$ at the quarter level and reported prevalences ranging from 15.4\% (Paraná, $\mathrm{n}=17$ herds; Saab et al., 2014) to $34.3 \%$ (São Paulo, $n=5$ herds; Bueno et al., 2002). Few studies have reported the incidence of SM in Brazilian dairy herds. Oliveira et al. (2013) reported that the incidence of SM in Minas Gerais ( $\mathrm{n}=5$ herds) was $33 \%$.

Nonetheless, the studies conducted thus far were limited due to the inclusion of small samples of cows and herds and the selection of herds from specific regions of the country. Such characteristics limit extrapolation of the results to larger populations of herds. Another limitation of most previous studies is that both prevalence and incidence of SM were estimated using the California Mastitis Test, which uses a threshold of traces (slight reaction) to define a case of SM. The test has subjective interpretation and provides a less accurate estimate of SCC than cell counting, resulting in a greater proportion of errors, such as false-negative results (Brito et al., 1997; Fosgate et al., 2013).

Thus, new studies that include larger samples of herds and that are based on DHIA SCC are needed to quantify the scope of the mastitis problem in Brazil. Estimating the prevalence and incidence of SM and describing longitudinal changes would be valuable to government agencies, dairy industries, and milk producers for developing large-scale milk quality programs. The objectives of this study were to estimate epidemiological indices of SM (prevalence and incidence) in a large population of Brazilian dairy herds and to describe how these indices changed over time.

\section{MATERIALS AND METHODS}

\section{Study Design, Selection of Herds, and Preparation of the Data Set}

The Strengthening the Reporting of Observational Studies in Epidemiology (STROBE) statement (Sargeant and O'Connor, 2014) was used as a guideline to report the results of this study. This research was designed as a longitudinal retrospective study. The original data set comprised individual cow SCC (composite milk samples) from 18,316 TD of all herds $(\mathrm{n}=1,809)$ that participated in a DHIA program between January 2011 and May 2015. Herds were located in 3 Brazilian regions: South (Paraná), Southeast (São Paulo, Minas Gerais, Rio de Janeiro, and Espírito Santo), and other (Pará, Goiás, Ceará, and Bahia). Herds were excluded ( $\mathrm{n}=3,742$ tests from 1,188 herds) from the data set if they had $\leq 10$ DHIA tests performed during the study period. Only DHIA tests that included $\geq 10$ lactating cows and that were performed at $30 \pm 10$-d intervals were used for analysis (5,499 tests from 48 herds were excluded for these reasons).

For a given TD, it was possible that farmers sent milk samples from a fraction of the lactating cows as opposed to testing the entire lactating herd. To minimize this problem, herds with a large variation in the number of lactating cows in consecutive DHIA TD were excluded from the study. To identify these herds, the coefficient of variation of the number of lactating cows tested on each TD during the study period was calculated for each herd. Herds with a coefficient of variation $\geq 25 \%$ were excluded from the analysis $(\mathrm{n}=790$ tests from 56 herds). This cut-off point was defined based on the 90th percentile of the coefficient of variation distribution of all herds and therefore excluded $10 \%$ of the herds with the largest variation in the number of cows tested. After all exclusions, the final data set used for analysis included 8,285 TD from 517 herds.

To categorize herds based on size, the average number of cows tested during the study period was calculated for each herd. The distribution of herd size was then analyzed, and the 33rd and 66th percentiles were used to categorize herds as small ( $\leq 55$ lactating cows), medium (55-120 lactating cows), or large ( $\geq 120$ lactating cows). Herds were further categorized based on the distribution (33rd and 66th percentiles) of the number of DHIA tests performed during the study period $(\leq 35$, $35-60$, and $\geq 60$ ).

\section{Definition of Epidemiological Indices}

A threshold of 200,000 cells/mL was used to define a case of SM (Dohoo and Leslie, 1991). The prevalence (\%) of SM was defined as the number of cows with SCC $\geq 200,000$ cells $/ \mathrm{mL}$ divided by the total number of tested cows on a given TD. The incidence of SM was defined as the number of cows whose SCC increased from $<200,000$ to $\geq 200,000$ cells $/ \mathrm{mL}$ over 2 consecutive TD divided by the sum of each cow's days at risk during this interval. Each case was assumed to have occurred at the middle of the interval between 2 consecutive tests (Dufour and Dohoo, 2013). For example, a cow that experienced a case of SM between 2 TD spaced by $28 \mathrm{~d}$ contributed with $14 \mathrm{~d}$ at risk. Cows that did not experience a case between 2 consecutive tests contributed the total number of days included in the interval. Because the time interval between 2 tests varied between 20 and $40 \mathrm{~d}$, the incidence rate (expressed as new cases per cow day at risk) was standardized to $30.5 \mathrm{~d}$ and expressed as new cases per cow month at risk (Dufour and Dohoo, 2013). 

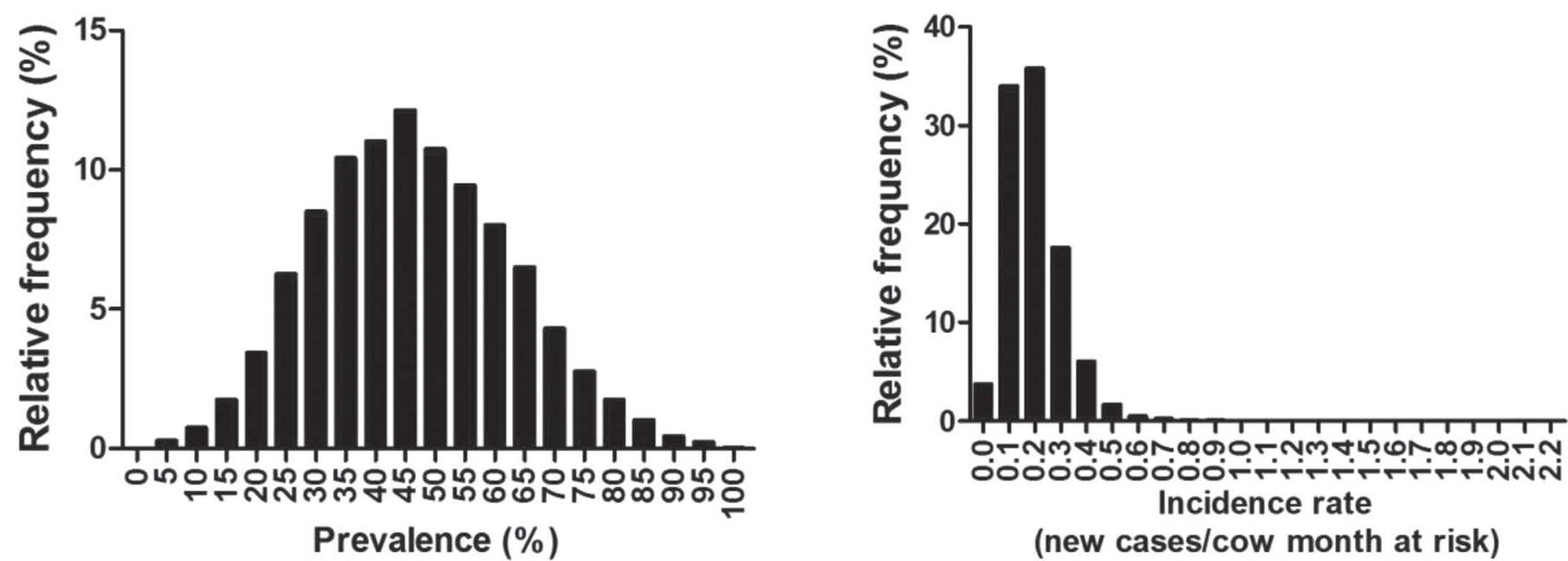

Figure 1. Distribution of prevalence and incidence rate of subclinical mastitis. The data set included 8,285 DHIA tests from 517 herds performed between January 2011 and May 2015.

\section{Statistical Analysis}

The distribution of the prevalence and incidence rate of SM was analyzed visually using histograms and normal probability plots, and descriptive statistics were produced accordingly. Prevalence was normally distributed, and the distribution of incidence was skewed due to the presence of large values (Figure 1).

Initially, a generalized linear model (Littell et al., 2006; PROC GLIMMIX, SAS Institute Inc., Cary, NC) was used to compare the incidence rate of SM between years, regions, and herd size categories. The response variable was the number of new cases that occurred between 2 DHIA TD (the offset was the log of the cow days at risk during the interval), and explanatory variables were year, herd size, region, and number of DHIA tests performed per herd during the study period. The heterogeneous first-order autoregressive covariance structure was used to model the unequally spaced repeated measurements within the same farm. Both the Poisson and the negative binomial distribution were first attempted but resulted in nonconvergence of the models.

The log-normal distribution was then used in the model and resulted in a good fit to the data (as assessed by analyzing the residuals). A backward variable selection procedure was used to select a final model, which retained only the explanatory variables that remained statistically significant $(P<0.05)$. The structure of the final model was as follows:

$$
\log \left(Y_{i j}\right)=\alpha+\beta_{i j}(X)+\delta_{j}
$$

where $Y$ was a continuous response variable representing the incidence rate of SM (new cases per cow month at risk), $\alpha$ was the intercept, $\beta_{i j}(X)$ was the $i$ th coefficient for the $i$ th explanatory variable (year and number of DHIA tests performed per herd during the study period), and $\delta_{j}$ was a random term used to model repeated measurements within the $j$ th farm. The heterogeneous first-order autoregressive covariance structure was used to model the unequally spaced repeated measurements within the same farm.

A similar modeling approach was used to compare the prevalence of SM (normally distributed) between the levels of the explanatory variables. The structure of the final model was as follows:

$$
Y_{i j}=\alpha+\beta_{i j}(X)+\delta_{j}
$$

where $Y$ was a continuous variable representing the mean prevalence (\%) of SM at a given TD, $\alpha$ was the intercept, $\beta_{i j}(X)$ was the $i$ th coefficient for the ith explanatory variable (year and number of DHIA tests performed per herd during the study period), and $\delta_{j}$ was a random term used to model the repeated measurements within the $j$ th farm. The heterogeneous first-order autoregressive covariance structure was used to model the unequally spaced repeated measurements within the same farm.

The Wilcoxon rank-sum test (PROC NPAR1WAY, SAS Institute Inc.) was used to compare (1) herd size among the regions studied and (2) the number of DHIA tests performed per herd during the study period among regions and herd size categories. Statistical analyses declared significance at 0.05 . 


\section{RESULTS}

The final data set used for analysis included 8,285 TD from 517 herds. Most herds (92\%) were in the Southeast, followed by the South $(6 \%)$ and other $(2 \%)$. As expected due to the exclusion criteria, the median interval between the DHIA tests performed per herd during the study period was $30 \mathrm{~d}$ (range $=20-40 \mathrm{~d}$ ). The median herd size was 83 (range $=11-1,348$ lactating cows). The median herd size was 39,82 , and 197 cows for small, medium, and large herds, respectively. The median herd size by region was 87 (range $=$ 11-1,348 lactating cows) in the Southeast, 45 (range $=$ 16-502 lactating cows) in the South, and 261 (range $=$ 24-855 lactating cows) in the other regions $(P<0.01)$.

The median number of DHIA tests performed on each herd during the study period was 27 (range $=$ 11-138). The median number of DHIA tests performed per herd was 23 (range $=11-138)$ for small herds, 27 (range $=11-104)$ for medium herds, and 34 (range $=$ 11-136) for large herds $(P<0.01)$. The median number of DHIA tests performed on each herd was 27 (range $=11-138$ ) in the Southeast, 33 (range $=11-77$ ) in the South, and 18 (range $=12-50)$ in the other regions combined $(P=0.07)$.

The prevalence and incidence distributions were normal and skewed to the right, respectively (Figure 1). The overall mean prevalence and incidence of SM including all tests performed during the study period were $46.4 \%$ and 0.17 new cases per cow month at risk, respectively (Table 1). Of the DHIA tests performed during the study period, $25 \%$ (third quartile) resulted in a prevalence of $>57.55 \%$ and an incidence of $>0.26$ new cases per cow month at risk.

Year and number of DHIA tests performed per herd during the study period remained as significant predictors of the prevalence of SM (Table 2). The prevalence of SM varied little from 2011 to 2015, and an increasing trend was observed over the years (Table 2; Figure 2). The prevalence of SM was greater in 2015 than in every previous year $(P<0.05$; Table 2$)$. The prevalence of SM was lower in herds that performed $\geq 60$ DHIA tests during the study period than in those that performed fewer tests $(P<0.05$; Table 2$)$ and was not different between regions $(P=0.29)$ or herd size categories $(P$ $=0.35$ ). The incidence of SM varied little during the study period (Table 2; Figure 2) and was not different among the regions studied.

\section{DISCUSSION}

The main goals of this study were to estimate the prevalence and incidence of SM in a large sample of Brazilian herds and to describe how these epidemiologi- cal indices changed over time. The overall mean prevalence $(46.4 \%)$ and incidence $(0.17$ new cases per cow month) of SM reported here are alarming due to their magnitude and lack of improvement during the study period. These results indicate that almost half of the cows within the population studied were subclinically infected and that approximately $18 \%$ of the healthy cows developed new cases of SM between 2 consecutive TD performed $30.5 \mathrm{~d}$ apart. Recommended goals for prevalence and incidence of SM in developed dairy regions should be below 15 and $8 \%$, respectively (Ruegg and Pantoja, 2013). These findings highlight that the establishment of large-scale milk quality programs must be a priority to improve the quality of milk produced in Brazil.

Several factors may explain the lack of effort toward improving milk quality. In Brazil, most producers are not subject to a payment program based on milk quality and possibly do not realize the actual production and financial losses attributable to SM (Valeeva et al., 2007), possibly reflecting a lack of education on the subject. Clinical mastitis seems to be more worrisome due to the visible signs of infection and direct losses attributable to treatment, milk discard, and veterinary services (Sadeghi-Sefidmazgi et al., 2011). Moreover, even for producers who are part of the DHIA, implementation of mastitis control programs is difficult and requires qualified professionals and a great deal of physical and mental effort (Jansen et al., 2010). The implementation of a DHIA program is a reality in developed dairy regions, but in Brazil there are few initiatives toward this direction. Last, the SCC and total bacteria count limits stipulated by the current legislation are not enforced (Ministério da Agricultura, Pecuária e Abastecimento, 2011). Thus, producers who exceed the legal SCC and total bacteria count limits frequently continue to sell their milk without receiving any kind of penalty or intervention.

The results of the present study indicate that both prevalence and incidence of SM were not different between herd size categories or the regions studied, reflecting the lack of initiatives toward improving milk quality. This finding is in contrast with the trend of better milk quality observed in larger herds in developed dairy regions. Plozza et al. (2011) categorized herds by prevalence of SM and found that herds with a prevalence of $<20 \%$ were larger (172 cows) than herds with a prevalence of $>30 \%$ (154 cows). In agreement, Smith et al. (2000) reported that small herds (25-99 cows) had more cases of SM compared with larger herds $(>100$ cows).

Incidence and prevalence of SM may be affected by regional, seasonal, and climatic differences (Nyman et al., 2007). One reason that may explain the lack 
OCCURRENCE OF SUBCLINICAL MASTITIS IN BRAZIL

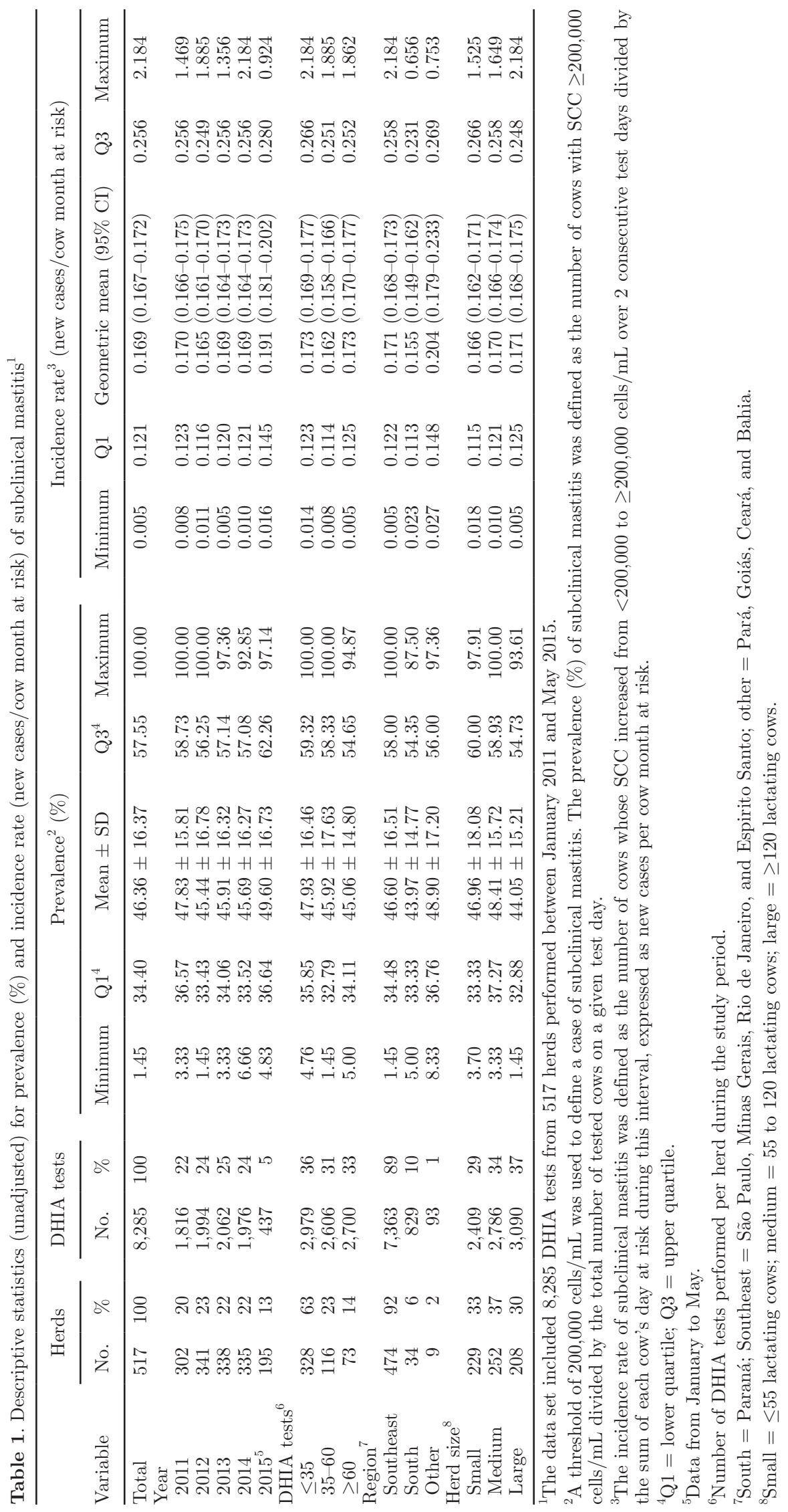


Table 2. Modeling results for prevalence (\%) and incidence rate (new cases/cow month at risk) of subclinical mastitis

\begin{tabular}{|c|c|c|c|c|c|}
\hline Variable & Coefficient & $\mathrm{SE}$ & $P$-value & $\begin{array}{l}\text { Adjusted } \\
\text { estimate }^{1}\end{array}$ & $95 \%$ CI \\
\hline \multicolumn{6}{|c|}{ Prevalence $^{2}(\%)$} \\
\hline Intercept & 49.63 & 0.99 & & & \\
\hline Year & & & $<0.001$ & & \\
\hline 2011 & -5.97 & 0.97 & & $45.25^{\mathrm{a}}$ & $43.97-46.53$ \\
\hline 2012 & -5.79 & 0.89 & & $45.43^{\mathrm{a}}$ & $44.30-46.55$ \\
\hline 2013 & -3.23 & 0.82 & & $47.99^{\mathrm{b}}$ & $46.87-49.10$ \\
\hline 2014 & -3.22 & 0.69 & & $48.00^{\mathrm{b}}$ & $46.85-49.15$ \\
\hline $2015^{3}$ & Referent & & & $51.22^{\mathrm{c}}$ & $49.69-52.75$ \\
\hline DHIA tests ${ }^{4}$ & & & 0.002 & & \\
\hline$\leq 35$ & 3.41 & 1.01 & & $49.40^{\mathrm{a}}$ & $48.12-50.69$ \\
\hline$\overline{35}$ to 60 & 1.34 & 1.10 & & $47.34^{\mathrm{ab}}$ & $45.78-48.89$ \\
\hline$\geq 60$ & Referent & & & $45.99^{\mathrm{b}}$ & $44.48-47.50$ \\
\hline \multicolumn{6}{|c|}{ Incidence rate ${ }^{5}$} \\
\hline Intercept & -1.621 & 0.031 & & & \\
\hline Year & & & $<0.001$ & & \\
\hline 2011 & -0.137 & 0.034 & & $0.169^{\mathrm{a}}$ & $0.163-0.175$ \\
\hline 2012 & -0.157 & 0.033 & & $0.166^{\mathrm{a}}$ & $0.160-0.171$ \\
\hline 2013 & -0.144 & 0.033 & & $0.168^{\mathrm{a}}$ & $0.163-0.173$ \\
\hline 2014 & -0.134 & 0.032 & & $0.170^{\mathrm{a}}$ & $0.164-0.175$ \\
\hline 2015 & Referent & & & $0.194^{\mathrm{b}}$ & $0.183-0.205$ \\
\hline DHIA tests & & & $<0.004$ & & \\
\hline$\leq 35$ & 0.002 & 0.020 & & $0.177^{\mathrm{a}}$ & $0.171-0.182$ \\
\hline$\overline{35}$ to 60 & -0.062 & 0.021 & & $0.166^{\mathrm{b}}$ & $0.161-0.171$ \\
\hline$\geq 60$ & Referent & & & $0.176^{\mathrm{a}}$ & $0.171-0.181$ \\
\hline
\end{tabular}

${ }^{\mathrm{a}-\mathrm{c}}$ Estimates within a column with different superscripts differ $(P<0.05$; Tukey's test for multiple comparisons).

${ }^{1}$ Adjusted prevalence and incidence estimates. For the incidence of subclinical mastitis, geometric means and confidence intervals are presented.

${ }^{2} \mathrm{~A}$ threshold of 200,000 cells $/ \mathrm{mL}$ was used to define a case of subclinical mastitis. The prevalence (\%) of subclinical mastitis was defined as the number of cows with SCC $\geq 200,000$ cells/mL divided by the total number of tested cows on a given test day. Model coefficients were derived from a repeated measures multivariable model assuming a normal distribution.

${ }^{3}$ Data from January to May.

${ }^{4}$ Number of DHIA tests performed per herd during the study period.

${ }^{5}$ The incidence rate of subclinical mastitis was defined as the number of cows whose SCC increased from $<200,000$ to $\geq 200,000$ cells $/ \mathrm{mL}$ over 2 consecutive test days divided by the sum of each cow's days at risk during this interval, expressed as new cases per cow month at risk. Model coefficients were derived from a repeated measures multivariable model assuming a log-normal distribution.

of differences among herd size categories and regions studied is the high prevalence of contagious pathogens in the population studied. The occurrence of contagious pathogens is less affected by environmental changes in humidity and temperature compared with the occurrence of environmental pathogens because the main form of transmission occurs during milking (Voltolini et al., 2001). Contagious pathogens, such as Staphylococcus aureus and Streptococcus agalactiae, continue to be the major problem in most regions of the country and are responsible for most cases of SM (Dias, 2007). For $S$. aureus, reported prevalence is $4.8 \%$ in Minas Gerais ( $\mathrm{n}=1,056$; Martins et al., 2015), 11.1\% in Pará ( $\mathrm{n}=172$; Mello et al., 2012), 11.4\% in Pernambuco (n = 1,080; Mota et al., 2012), $17.6 \%$ in Rio Grande do Sul ( $\mathrm{n}=227$; Bandeira et al., 2013), $17.7 \%$ in Pará ( $\mathrm{n}=62$; Oliveira et al., 2011), $17.8 \%$ in Goiás ( $\mathrm{n}=$ 83; Fontana et al., 2010), and $28.2 \%$ in Minas Gerais
( $\mathrm{n}=388$ cows; Cunha et al., 2015). For S. agalactiae, reported prevalence is $3.1 \%$ in Paraná $(\mathrm{n}=172$; Mello et al., 2012), 7.1\% in São Paulo $(\mathrm{n}=210$; Langoni et al., 2011), $11.1 \%$ in the South $(\mathrm{n}=1,382$; Jobim et al., 2010), 11.6\% in Goiás ( $\mathrm{n}=1,056$; Martins et al., 2015), and $13.7 \%$ in Minas Gerais $(\mathrm{n}=388$ cows; Cunha et al., 2015).

Routine analysis of individual cow SCC is essential for milk quality programs (Ruegg and Pantoja, 2013; Cardozo et al., 2015). By means of SCC analysis and calculation of epidemiological indices, producers have the necessary information to better understand mastitis in the herd as a problem and, consequently, seek solutions. Thus, it was expected that producers who had more DHIA tests performed during the study period were more interested in improving milk quality and therefore had lower prevalence and incidence of SM in their herds. 
It is important to note that the sample of herds included in this study is probably not representative of the country as a whole. After applying the exclusion criteria, the sample comprised herds that participated in a DHIA program and had $>10$ DHIA tests (which included $\geq 10$ lactating cows and were performed at 30 \pm 10 -d intervals) performed during the study period. Although these exclusion criteria significantly reduced the number of herds and tests $(18,316$ TD from 1,809 herds to 8,285 TD from 517 herds), such exclusions were important to improve the validity of the data.

Herds in DHIA have been encouraged to adopt management practices that can result in improvement of mastitis epidemiological indices (Rodrigues and Ruegg, 2005). Thus, the actual prevalence and incidence of $\mathrm{SM}$ in the country could be even greater than those reported here. As opposed to many DHIA in developed dairy regions, most producers did not have DHIA milk production records coupled with individual cow SCC. Moreover, the data set did not include information that could have been used to improve the understanding of the indices studied, such as DIM, milk production, parity, bulk tank SCC, breed, management practices, and type of facilities. This limited the ability to extrapolate the results of this study and encourages further surveys at the national level that include a representative sample of Brazilian dairy herds and additional milk quality indicators.

Descriptive data on herd characteristics and milk production systems are scarce in Brazil. According to the Brazilian Census of Agriculture, there were 1.35 million dairy herds in Brazil in 2006 (IBGE, 2006), of which 250,000 legally marketed milk in 2013 (Associação Leite Brasil, 2013). It has been estimated that $70 \%$ of Brazilian cows are crossbreeds of European (mostly Holstein and Jersey) and Asian (Bos indicus) breeds (Miranda and Freitas, 2009). Almost all herds (99\%) are managed in extensive (grazing only) and semiextensive (grazing with some degree of forage and concentrate supplementation) systems. These herds have, on average, 30 cows that produce $<2,000 \mathrm{~kg} / \mathrm{cow}$ per year and produce $70.5 \%$ of the country's total milk supply (Assis et al., 2005). In contrast, several developed herds (located mostly in the South and Southeast regions of the country) comprising primarily Holstein cows produce $>4,500 \mathrm{~kg} / \mathrm{cow}$ per year and are housed in confinement systems, such as freestalls. These herds represent approximately $1 \%$ of the total number of herds and produce $4.6 \%$ of the country's total milk supply (Assis et al., 2005).

The South is the largest milk producer in Brazil (produces $35 \%$ of the milk, includes $30.6 \%$ of the total number of herds, and has an average production of $2,900 \mathrm{~kg} / \mathrm{cow}$ per year) followed by the Southeast (produces $34 \%$ of the milk, includes $23 \%$ of the herds, and has an average production of $1,597 \mathrm{~kg} / \mathrm{cow}$ per year), and other regions combined (produces $31 \%$ of the milk, includes $46.4 \%$ of the herds, and has an average production of $1,051 \mathrm{~kg} / \mathrm{cow}$ per year; IBGE, 2006; EMBRAPA, 2017). Our sample comprised mostly

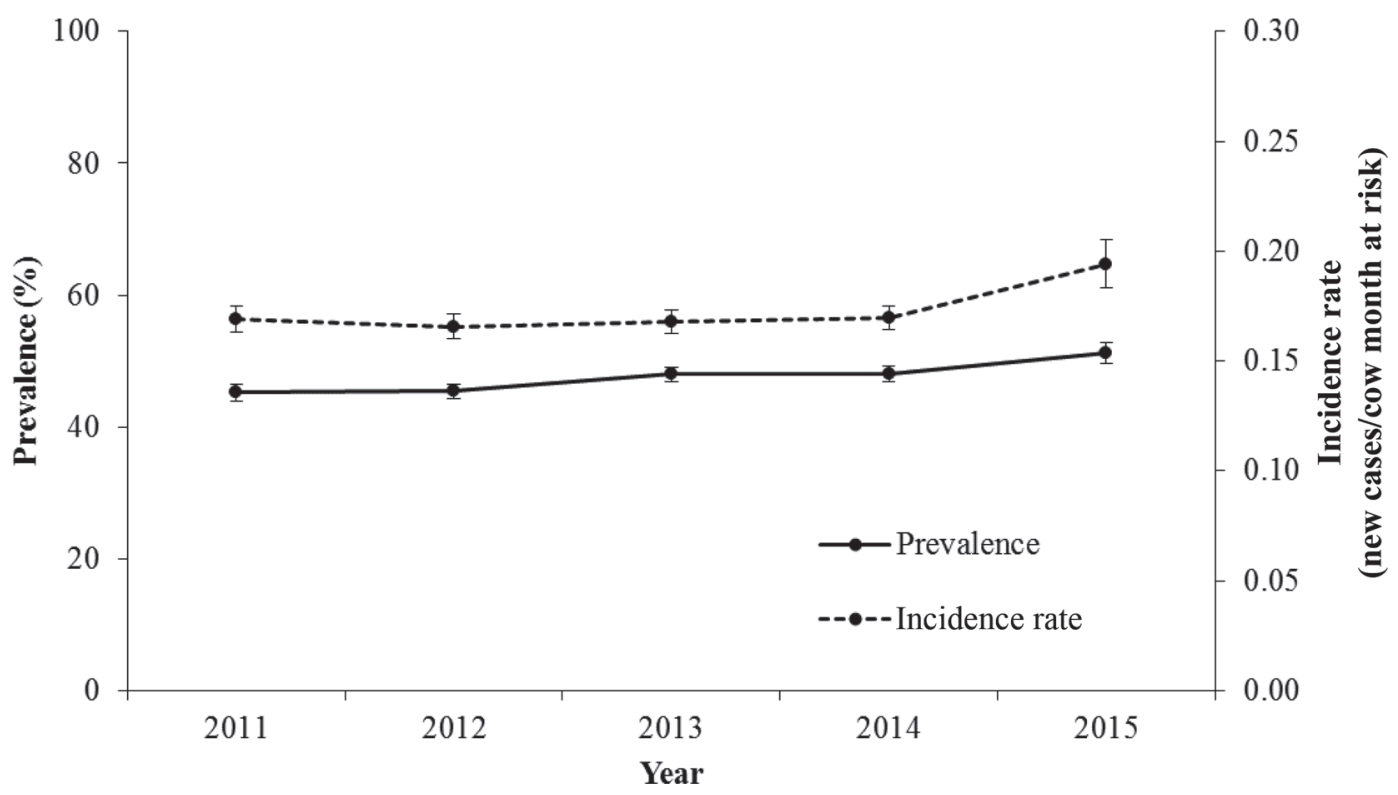

Figure 2. Adjusted prevalence (mean) and incidence rate (geometric mean) of subclinical mastitis by year. Errors bars represent $95 \%$ confidence intervals. The data set included 8,285 DHIA tests from 517 herds performed between January 2011 and May 2015. 
southeastern herds. Differences between regions may not have been evidenced because herds were distributed unevenly between regions, which possibly reduced the power of statistical testing and representativeness of some regions (South and others).

Both prevalence and incidence of SM were higher in 2015 than in previous years. Nonetheless, data from 2015 did not include the colder months of the year (July and August), which probably resulted in overestimation of prevalence and incidence of SM.

It is important to note that any SM case definition based on SCC will not be perfect. It is possible that cows whose SCC fluctuated across the threshold of 200,000 cells $/ \mathrm{mL}$ in consecutive months were actually chronically infected, in which case an SCC increase from $<200,000$ to $>200,000$ cells $/ \mathrm{mL}$ would be misclassified as a new case. In this case, the incidence of SM would be overestimated. In contrast, such fluctuating patterns could represent actual new cases of SM that occurred in cows who had experienced a spontaneous cure and then were reinfected on the same or different quarter(s). Because these SCC patterns could be validated only by means of microbiological examination of milk, we did not pursue further investigations.

\section{CONCLUSIONS}

Prevalence and incidence of SM in the 517 herds studied were not only high but also did not improve over the study period. These trends were observed across all herd size categories and regions studied. Results of this study highlight the need to establish large-scale milk quality programs in Brazil.

\section{ACKNOWLEDGMENTS}

The authors thank the Coordenação de Aperfeiçoamento de Pessoal do Nível Superior, which made it possible to carry out this research. They also thank the Conselho Nacional de Desenvolvimento Científico e Tecnológico (Brasilia, Brazil) for providing the scholarship to Marcos Busanello.

\section{REFERENCES}

Assis, A. G., L. A. Stock, O. F. Campos, A. T. Gomes, R. Zoccal, and M. R. Silva. 2005. Sistemas de produção de leite no Brasil. Empresa Brasileira de Pesquisa Agropecuária, Juiz de Fora, Brazil.

Associação Leite Brasil. 2013. Cai o número de produtores de leite do país. Accessed Mar. 29, 2017. https://www.milkpoint.com.br/ cadeia-do-leite/giro-lacteo/cai-o-numero-de-produtores-de-leitedo-pais-85477n.aspx.

Bandeira, F. S., T. Picoli, J. L. Zani, W. P. Silva, and G. Fischer. 2013. Frequência de Staphylococcus aureus em casos de mastite bovina subclínica, na região sul do Rio Grande do Sul. Arq. Inst. Biol. (Sao Paulo) 80:1-6. https://doi.org/10.1590/S180816572013000100001.
Barbano, D. M., Y. Ma, and M. V. Santos. 2006. Influence of raw milk quality on fluid milk shelf life. J. Dairy Sci. 89(Suppl. 1):E15-E19. https://doi.org/10.3168/jds.S0022-0302(06)72360-8.

Brito, J. R. F., G. A. V. Caldeira, R. S. Verneque, and M. A. V. P. Brito. 1997. Sensibilidade e especificidade do California Mastitis Test como recurso diagnóstico da mastite subclínica em relação à contagem de células somáticas. Pesqui. Vet. Bras. 2:49-53. https://doi. org/10.1590/S0100-736X1997000200002.

Bueno, V. F. F., R. S. Nicolau, A. J. Mesquita, A. R. Ribeiro, J A. B. Silva, E. O. Costa, K. O. Coelho, and R. B. Neves. 2002 Mastite bovina clínica e subclínica na região de Pirassununga, SP: Frequências e redução na produção. Ciência Animal Brasileira $3: 47-52$.

Cardozo, L. L., A. Thaler Neto, G. N. Souza, L. C. A. Picinin, N. C. Felipus, N. L. M. Reche, F. A. Schmidt, D. Werncke, and E. E. Simon. 2015. Risk factors for the occurrence of new and chronic cases of subclinical mastitis in dairy herds in southern Brazil. J. Dairy Sci. 98:7675-7685. https://doi.org/10.3168/jds.2014-8913.

Costa, E. O., A. R. Ribeiro, E. T. Watanabe, J. A. B. Silva, F. Garino Júnior, N. R. Benites, and A. M. Horiuti. 1999. Mastite subclínica: Prejuízos causados e os custos de prevenção em propriedades leiteiras. Revista Napgama. 2:16-20.

Cunha, A. F., L. J. Bragança, L. C. Quintão, S. Q. Silva, F. N. Souza, and M. M. O. P. Cerqueira. 2015. Prevalência, etiologia e fatores de risco de mastite subclínica em rebanhos leiteiros de Viçosa-MG. Acta Veterinaria Brasilica 9:160-166. https://doi.org/10.21708/ avb.2015.9.2.5262.

Dias, R. V. C. 2007. Principais métodos de diagnóstico e controle da mastite bovina. Acta Veterinaria Brasílica 1:23-27. https://doi. org/10.21708/avb.2007.1.1.255.

Dohoo, I. R., and K. E. Leslie. 1991. Evaluation of changes in somatic cell counts as indicators of new intramammary infections. Prev. Vet. Med. 10:225-237. https://doi.org/10.1016/0167-5877(91)90006-N.

Dufour, S., and I. R. Dohoo. 2013. Monitoring herd incidence of intramammary infection in lactating cows using repeated longitudinal somatic cell count measurements. J. Dairy Sci. 96:1568-1580. https://doi.org/10.3168/jds.2012-5902.

EMBRAPA (Empresa Brasileira de Pesquisa Agropecuária). 2017. Indicadores: Leite e derivados. 64th ed. EMBRAPA, Juiz de Fora, Brazil.

Fontana, V. L. D. S., M. J. S. M. Giannini, C. Q. F. Leite, E. T Miranda, A. M. F. Almeida, C. A. P. Fontana, C. M. Souza, and A. E. Stella. 2010. Etiologia da mastite bovina subclínica, sensibilidade dos agentes às drogas antimicrobianas e detecção do gene da $\beta$-lactamase em Staphylococcus aureus. Vet. Zootec. 17:552-559.

Fosgate, G. T., I. M. Petzer, and J. Karzis. 2013. Sensitivity and specificity of a hand-held milk electrical conductivity meter compared to the California mastitis test for mastitis in dairy cattle. Vet. J. 196:98-102. https://doi.org/10.1016/j.tvjl.2012.07.026.

IBGE (Instituto Brasileiro de Geografia e Estatísticas). 2006. Censo agropecuário: Brasil, grandes regiões e unidades da federação. 10th ed. IBGE, Rio de Janeiro, Brazil.

Jansen, J., R. J. Renes, and T. J. G. M. Lam. 2010. Evaluation of two communication strategies to improve udder health management. J. Dairy Sci. 93:604-612. https://doi.org/10.3168/jds.2009-2531.

Jobim, M. B., M. A. Lopes, G. M. Costa, and F. A. Demeu. 2010 Patógenos associados à mastite bovina em rebanhos leiteiros na região sul do Brasil. B. Indústr. Anim. 67:175-181.

Langoni, H., D. S. Po, J. C. C. Citadella, F. Laurino, P. Y. FaccioliMartins, S. B. Lucheis, B. D. Menozzi, and A. V. Silva. 2011 Aspectos microbiológicos e de qualidade do leite bovino. Pesqui. Vet. Bras. 31:1059-1065.

Littell, R. C., G. A. Milliken, W. W. Stroup, R. D. Wolfinger, and O. Schabenberger. 2006. SAS for Mixed Models. 2nd ed. SAS Institute Inc., Cary, NC.

Martins, J. D., E. S. Nicolau, A. J. Mesquita, and E. A. G. V. Jardim. 2015. Mastite subclínica em rebanhos leiteiros de propriedades rurais de Goiás. Rev. Bras. Hig. San. Anim. 9:206-214. https://doi. org/10.5935/1981-2965.20150019.

McDermott, M. P., H. N. Erb, and R. P. Natzke. 1982. Predictability by somatic cell counts related to prevalence of intramammary 
infection within herds. J. Dairy Sci. 65:1535-1539. https://doi. org/10.3168/jds.S0022-0302(82)82378-3.

Mello, P. L., R. O. Agostinis, E. M. Barzon, R. B. Colombo, A. V. Silva, and L. A. Martins. 2012. Prevalência da mastite subclínica e associação dos agentes etiológicos com a contagem de células somáticas de vacas leiteiras da região sudoeste do Paraná. Vet. Zootec. 19:513-521.

Ministério da Agricultura, Pecuária e Abastecimento. 2011. Instrução Normativa 62, de 29 de dezembro de 2011. Regulamento técnico de produção, identidade e qualidade do leite tipo A, regulamento técnico de identidade e qualidade de leite cru refrigerado, regulamento técnico de identidade e qualidade de leite pasteurizado e regulamento técnico da coleta de leite cru refrigerado e seu transporte a granel. Ministério da Agricultura, Pecuária e Abastecimento, Brasília, Brazil.

Miranda, J. E. C., and A. F. Freitas. 2009. Raças e Tipos de Cruzamentos para Produção de Leite. 1st ed. Empresa Brasileira de Pesquisa Agropecuária, Juiz de Fora, Brazil.

Mota, R. A., E. S. Medeiros, M. V. Santos, J. W. Pinheiro Júnior, A. P. B. L. Moura, and L. C. A. Coutinho. 2012. Participação dos Staphylococcus spp na etiologia das mastites em bovinos leiteiros no estado de Pernambuco (Brasil). Ciência Animal Brasileira 13:124-130. https://doi.org/10.5216/cab.v13i1.3790.

Nyman, A. K., T. Ekman, U. Emanuelson, A. H. Gustafsson, K. Holtenius, K. P. Waller, and C. H. Sandgren. 2007. Risk factors associated with the incidence of veterinary-treated clinical mastitis in Swedish dairy herds with a high milk yield and a low prevalence of subclinical mastitis. Prev. Vet. Med. 78:142-160. https://doi. org/10.1016/j.prevetmed.2006.10.002.

Oliveira, A. J., G. F. Moraes, I. C. Ferreira, C. P. Monteiro, and A. D. F. Carvalho. 2013. Mastite clínica e subclínica em pequenas propriedades leiteiras no município de Araguari-MG. Vet. Not. 19:7-13.

Oliveira, C. M. C., M. G. S. Sousa, N. S. Silva, C. L. Mendonça, J. A. S. Silveira, R. P. Oaigen, S. J. T. Andrade, and J. D. Barbosa. 2011. Prevalência e etiologia da mastite bovina na bacia leiteira de Rondon do Pará, estado do Pará. Pesqui. Vet. Bras. 31:104-110. https://doi.org/10.1590/S0100-736X2011000200002.

Oliveira, U. V., G. S. Galvão, A. R. R. Paixão, and A. D. Munhoz. 2010. Ocorrência, etiologia infecciosa e fatores de risco associados à mastite bovina na microrregião Itabuna-Ilhéus, Bahia. Rev. Bras. Saúde Prod. Anim. 11:630-640.

Plozza, K., J. J. Lievaart, G. Potts, and H. W. Barkema. 2011. Subclinical mastitis and associated risk factors on dairy farms in New
South Wales. Aust. Vet. J. 89:41-46. https://doi.org/10.1111/ j.1751-0813.2010.00649.x.

Rodrigues, A. C. O., and P. L. Ruegg. 2005. Actions and outcomes of Wisconsin dairy farms completing milk quality teams. J. Dairy Sci 88:2672-2680. https://doi.org/10.3168/jds.S0022-0302(05)729441.

Ruegg, P., and J. C. F. Pantoja. 2013. Understanding and using somatic cell counts to improve milk quality. Ir. J. Agric. Food Res. 52:101-117.

Ruegg, P. L. 2003. Investigation of mastitis problems on farms. Vet. Clin. N. Am. Food Anim. Prac. 19:47-74. https://doi.org/10.1016/ S0749-0720(02)00078-6.

Saab, A. B., T. O. Zamprogna, T. M. Lucas, K. C. Martini, P. L Mello, A. V. Silva, and L. A. Martins. 2014. Prevalência e etiologia da mastite bovina na região de Nova Tebas, Paraná. Semina: Ciências Agrárias 35:835-843. https://doi.org/10.5433/16790359.2014v35n2p835

Sadeghi-Sefidmazgi, A., M. Moradi-Shahrbabak, A. Nejati-Javaremi, S. R. Miraei-Ashtiani, and P. R. Amer. 2011. Estimation of economic values and financial losses associated with clinical mastitis and somatic cell score in Holstein dairy cattle. Animal 5:33-42. https://doi.org/10.1017/S1751731110001655.

Sargeant, J. M., and A. M. O'Connor. 2014. Issues of reporting in observational studies in veterinary medicine. Prev. Vet. Med. 113:323-330. https://doi.org/10.1016/j.prevetmed.2013.09.004.

Smith, J. W., L. O. Ely, and A. M. Chapa. 2000. Effect of region, herd size, and milk production on reasons cows leave the herd. J. Dairy Sci. 83:2980-2987. https://doi.org/10.3168/jds.S00220302(00)75198-8.

Valeeva, N. I., T. J. G. M. Lam, and H. Hogeveen. 2007. Motivation of dairy farmers to improve mastitis management. J. Dairy Sci. 90:4466-4477. https://doi.org/10.3168/jds.2007-0095.

Voltolini, T. V., G. T. Santos, M. A. Zambom, N. P. Ribas, E. E. Müller, J. C. Damasceno, L. C. V. Ítavo, and D. R. Veiga. 2001. Influência dos estádios de lactação sobre a contagem de células somáticas do leite de vacas da raça holandesa e identificação de patógenos causadores de mastite no rebanho. Acta Scientiarum Anim. Sci. 23:961-966. https://doi.org/10.4025/actascianimsci. v23i0.2652.

Ziech, R. E., C. Balzan, C. R. R. Nilles, A. C. Vargas, C. Lampugnani, and A. P. Perin. 2013. Ocorrência e etiologia da mastite subclínica e avaliação da qualidade microbiológica do leite cru na região central do RS. Vet. Zootec. 20:139-140. 